\title{
HUMILITY AND ETHICAL DEVELOPMENT
}

\author{
Cathy Mason
}

Humility is a rare virtue and an unfashionable one and one which is often hard to discern. Only rarely does one meet someone in whom it positively shines, in whom one apprehends with amazement the absence of the anxious avaricious tentacles of the self.... And although [the humble $\mathrm{man}]$ is not by definition the good man perhaps he is the kind of man who is most likely of all to become good.

-Iris Murdoch, The Sovereignty of Good

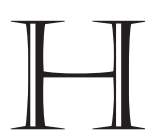

UMILITY CAN SEEM like a somewhat "unfashionable" virtue: the word can conjure an image of cringing servility, unduly romanticized feelings of inferiority, or a level of self-denial which seems ill placed in a life well lived. ${ }^{1}$ But the term can also capture something of great ethical importance. In this paper, I will propose an account of humility that attempts to capture this moral significance. I will then explore the connection between humility and ethical development, seeking to understand why Murdoch identifies the humble person as likely to become good. If such a connection is vindicated, it suggests that humility is valuable twice over: it has intrinsic worth but is also instrumentally valuable, enabling us to become better people.

I will begin, in section 1, by gesturing to the everyday conception of humility through offering two literary examples in which the characters' lack of humility is particularly salient. In section 2, I will explore Nicolas Bommarito's account of

1 O'Hagan thus writes: “Humility' might arouse worries about failures of self-respect”

("Modesty as an Excellence in Moral Perspective Taking," 1120). Raterman states:

One suspicion that bears entertaining is that modesty [which Raterman takes to be interchangeable with humility] was labeled a virtue by those who had some interest in keeping people subjugated. To teach people that modesty is a virtue is to teach them to divert credit for their skills and accomplishments away from themselves, so that when they demand their "just desert," the amount they take themselves to be justified in demanding (in terms of rights, money, influence, standard of living, etc.) will be less than if they took more credit. Perhaps they will even consider the very act of demanding their just desert to be immodest. ("On Modesty," 221-22) 
humility, which importantly brings together two distinct aspects of humility. ${ }^{2}$ I will suggest, however, that it falls short of identifying the core of the notion. In section 3, I will offer my own account of humility as the trait of not valorizing relative superiority. I will suggest that this explains the way that humility manifests, and why such a trait would be virtuous. In section 4 , I will briefly consider three objections. In section 5, I will argue that humility thus understood is importantly connected with ethical development. I will thus argue that the humble person is both good (in a certain respect) and, following Murdoch, likely to become good. $^{3}$

\section{TWO PARADIGMS OF LACKING HUMILITY}

Despite Murdoch's contention that humility can often be hard to discern, it seems possible to identify at least some paradigm cases of it—as well as paradigm cases of individuals lacking humility. The two examples below are paradigm cases of lacking humility. In depicting the absence of humility, they illuminate something at the heart of what is crucial to it. The first is taken from Charles Dickens's David Copperfield, in which Uriah Heep continually asserts that he is "a humble man":

"When I was quite a young boy," said Uriah, "I got to know what umbleness did, and I took to it. I ate umble pie with an appetite. I stopped at the umble point of my learning, and says I, 'Hold hard!' When you offered to teach me Latin, I knew better. 'People like to be above you,' says father, 'keep yourself down.' I am very umble to the present moment, Master Copperfield, but I've got a little power!"

And he said all this - I knew, as I saw his face in the moonlight - that I might understand he was resolved to recompense himself by using his power. ${ }^{4}$

Uriah's continual claims to be humble here contribute to his overall unpleasantness. He claims to be humble in order to ingratiate himself with others, and he is ultimately driven by a desire to be superior and have power over others. His as-

2 Bommarito, "Modesty as a Virtue of Attention."

3 Although this paper defends Murdoch's insight that humility is connected with ethical development, it should be noted that I am not seeking to provide an interpretation of specifically Murdochian humility. Moreover, the claim I seek to defend will be weaker than Murdoch's: I will argue that humility is important for ethical development, but will not explore the stronger claim that the humble person is most likely to become good.

4 Dickens, David Copperfield, 491. 
sertions regarding his own humility are particularly striking because they seem to be self-undermining: his claims are not only untrue, but are also undermined by the very purpose to which he puts them. For instance, his self-satisfied claim to have "a little power" here sits uncomfortably following an assertion of his humility. Dickens thus describes him as exhibiting "false humility." This striking feature of this case is frequently regarded as holding for all or at least many instances of asserting one's own humility. ${ }^{5}$ An account of humility should explain why Uriah Heep is not humble and should shed light on the self-undermining nature of his claims.

A second example comes from George Eliot's Daniel Deronda. The two protagonists of the novel, Daniel and Gwendolen, stand opposed in almost every respect. Gwendolen has for all of her life been surrounded by servile flattery, and at the beginning of the novel is complacent about her own superiority. She is particularly proud of her singing, until she is told by someone she recognizes as a true musical genius that she possesses no particular musical talent. Upon having this realization, Gwendolen ceases to be able to enjoy music. The following dialogue occurs when Daniel urges her to enjoy others' singing and suggests that hearing excellence in others will entice Gwendolen to pick it up once more:

"I should rather think my resolution [to stop singing] would be confirmed," said Gwendolen. "I don't feel able to follow your advice of enjoying my own middlingness."

"For my part," said [Daniel], "people who do anything finely always inspirit me to try. I don't mean that they make me believe I can do it as well. But they make the thing, whatever it may be, seem worthy to be done. I can bear to think my own music not good for much, but the world would be more dismal if I thought music itself not good for much. Excellence encourages one about life generally; it shows the spiritual wealth of the world."

"But then if we can't imitate it, it only makes our own life seem the tamer," said Gwendolen, in a mood to resent encouragement founded on her own insignificance. ${ }^{6}$

At this point in the novel, Gwendolen is no longer ignorant of the limits of her talent, but her inability to continue to enjoy music indicates that she lacks humility. Eliot contrasts this with Daniel's ability to enjoy music despite his lack

5 Driver, "The Virtues of Ignorance" and Uneasy Virtue; Kellenberger, "Humility"; and Bommarito, "Modesty as a Virtue of Attention," for example, all discuss the peculiarity of asserting that one is humble.

6 Eliot, Daniel Deronda, 148. 
of exceptional talent: Gwendolen's inability to enjoy music seems like a natural continuation of her earlier arrogance. ${ }^{7}$ But Gwendolen's lack of humility is also a barrier to her becoming better. It prevents her from immersing herself in the world (as Daniel advises her), which means she is unable to escape her self-centered preoccupations. By the end of the novel she is a sadly stunted character. I will suggest that there is a general connection between humility and ethical development that explains this case.

In depicting individuals who lack humility, the above examples depict people who are vicious in different respects. Virtues are generally thought to stand in opposition to certain vices. Lack of a virtue, that is, is realized in the possession of opposing vices. Courage, for instance, is thought to stand in opposition to cowardice and recklessness. Lack of humility, too, entails possession of certain vices. In the above example, Uriah Heep is plausibly invidiously envious, and Gwendolen's moral unattractiveness lies in her arrogance or conceit. Both thus lack the humility that would overcome their vices. ${ }^{8}$

In order to understand these cases, it is first necessary to have a more explicit grasp of what humility is. In the next section I will explore one recent account of humility, but argue that it misidentifies the core of humility. In sections 3 and 4 , I will then set forward and defend my own account, which sheds light on what is morally lacking in Uriah and why his assertions of humility are problematic. In section 5, I will explore the connection between my notion of humility and ethical development, explaining why it is that Gwendolen's lack of humility is a barrier to her ethical improvement.

\section{BOMMARITO: HUMILITY AS A PATTERN OF ATTENTION}

Bommarito has recently set forward an account of humility that he suggests captures its moral value. ${ }^{9}$ He argues that there is a distinctive subset of virtues that

7 Calhoun, “On Being Content with Imperfection," suggests that contentment with imperfection can itself be a kind of virtue.

8 Kellenberger, "Humility," describes humility as opposed to "the axis of pride and shame," and thus opposed to vices of arrogance, envy or jealousy, and self-abasement.

9 Bommarito proposes this view in a paper titled "Modesty as a Virtue of Attention," but explicitly states that he will "take the terms [modesty and humility] to be interchangeable" (93). He discusses others' views on humility, and at times refers to humility rather than modesty. The assumption that humility and modesty are interchangeable is widespread, shared by Raterman, "On Modesty"; Garcia, "Being Unimpressed with Ourselves"; Sinha, "Modernizing the Value of Humility"; Priest, "Intellectual Humility"; and O’Hagan, "Modesty as an Excellence in Moral Perspective Taking," among others. I am sympathetic to the idea that humility and modesty are importantly distinct. Nonetheless, since many have tak- 
are "virtues of attention," and that humility is one such virtue. These virtues, he claims, are "rooted in certain patterns of attention." ${ }^{10}$ The humble person, he claims, has a tendency not to attend to their own good qualities or achievements but instead will tend to attend to the good qualities of others. The humble person may sometimes attend to their own good qualities; but then it matters exactly what they attend to. For example, the humble person might attend to a good quality of their own but not to its value, or they might attend to the quality but direct their attention toward the good fortune enabling them to gain the quality in question. Bommarito suggests that in such cases, despite attending to their own good quality, the individual still exhibits patterns of attention appropriate to humility. He also puts this in terms of dwelling on one's good qualities or achievements: "Modesty does not demand inattention in the sense of a total lack of attention but in the sense that one does not $d w e l l$ on one's own good qualities." ${ }^{11}$

Extant accounts of humility focus on either self-directed or other-directed aspects of humility. ${ }^{12}$ In so doing, they tend to explain one aspect of humility but not the other. Self-directed accounts focus on the humble person's beliefs or attitudes about or toward their self. For example, Garcia claims that humble people "are unimpressed with their own admired or envied features," and Flanagan suggests of the related concept of modesty that it involves not overestimating oneself. ${ }^{13}$ Other-directed accounts focus on the humble person's attitudes or

en humility and modesty to be identical, and take their accounts to shed light on both, I will engage with some of the literature on modesty.

Bommarito, "Modesty as a Virtue of Attention," 93.

Bommarito, "Modesty as a Virtue of Attention," 108. Nadelhoffer et al. ("Some Varieties of Humility Worth Wanting") describe humility as consisting in low self-focus and high other-focus. I take their account to be similar to Bommarito's. As I argue below with regard to Bommarito's account, it seems that in order to capture the moral significance of this pattern of focus, one must stipulate that one focuses in this way for the right reasons (not, for example, because one is obsessively envious). Alternatively, such focus might be understood as normatively rich in the first place, but then it seems to be morally valuable in virtue of being a kind of care. In that case, an account is needed of what kind of care humility is grounded in.

This distinction is made by Garcia, who uses the terms "inward-directed" and "outward-directed" ("Being Unimpressed with Ourselves"). Byerly also draws on this distinction ("The Values and Varieties of Humility").

13 Garcia, "Being Unimpressed with Ourselves," 417; Flanagan, "Virtue and Ignorance." These are far from the only adherents to this approach. Driver suggests that "a modest person underestimates self-worth" ("The Virtues of Ignorance", 374). Raterman claims that the modest person has an "appropriate attitude" toward their own goodness ("On Modesty"). Richards suggests that humility involves withstanding pressures to think too much of ourselves ("Is 
behavior toward others. For example, Byerly describes humility as "preferring to promote others' good rather than one's own." ${ }^{14}$ Since such accounts focus on a single dimension of humility, they tend to struggle to shed light on the range of ways it can be manifested. For example, the self-directed accounts will fail to explain why the humble person is characteristically patient and generous with others (the manifestations of humility that other-directed accounts regard as central), whereas other-directed accounts fail to explain the humble person's distinctive attitudes to their self (which self-directed accounts regard as central).

Bommarito's account does not fall neatly into either category. He takes the pattern of attention constituting humility to have both other- and self-directed poles. ${ }^{15}$ Bommarito explains the self- and other-directed aspects of humility as resulting from a broad overall pattern of attention to oneself and others. His account, then, has an advantage over extant accounts in that it seems capable of explaining a wider variety of manifestations of humility. In this section I will first explain Bommarito's account. I will then suggest that it is nonetheless ultimately inadequate as an account of humility since it misidentifies a manifestation of humility as constitutive of it. Moreover, I will argue that a particular care is at the heart of humility and that this sheds light on why certain patterns of attention manifest humility.

On Bommarito's account, humility requires more than simply a pattern of attention. It also requires that the humble person possess a good quality to be humble about. After all, if one does not possess a good quality to direct one's attention away from, one is not being inattentive to it. Bommarito therefore describes humility as a dependent virtue, a virtue that can be attained only if one already possesses good qualities.

Bommarito is seeking to provide an account of something he takes to be a virtue. What would be virtuous about manifesting the patterns of attention he identifies? There is no simple connection between patterns of attention and virtue. There can be good reasons for attending to one's own good qualities (for example, to discern whether one is capable of taking on a new responsibility) and some reasons for attending to others' good qualities that render such attention morally suspect (for example, enviously doing so). To secure the idea that hu-

Humility a Virtue?"). Although there are a range of tendencies identified here as humility, they all focus on the self-directed aspect of humility.

Byerly, "The Values and Varieties of Humility," 890.

15

O'Hagan also offers an account on which humility is neither self- nor other-directed. On her account, it involves "excellence in moral perspective taking": the humble person is committed to recognizing persons as equally morally valuable ("Modesty as an Excellence in Moral Perspective Taking"). 
mility is a virtue, Bommarito suggests that the patterns of attention exhibited by the humble person must be grounded in the agent's values, desires, or concerns. Such concerns or desires, he claims, must be good. He therefore claims that the humble person has particular reasons for attending to others' good qualities rather than their own:

They are modest if their inattention is the result of a lack of certain bad desires or concerns, such as a desire to ogle their own self-image. ${ }^{16}$

Bommarito thus suggests that whether a pattern of attention counts as humble depends not only upon the pattern of attention itself, but upon the reasons behind the pattern. He does not, however, offer a specific account of the desires or concerns that underlie humility:

The general account of modesty as a virtue of attention is not wedded to any particular account of the desires and values that make directed attention count as modest. As long as one accepts that our values and desires are often closely related to how we direct our attention, one can fill one's own preferred good and bad desires or values into the account. The specifics of these values and desires are irrelevant to the claim that modesty is a virtue of attention. ${ }^{17}$

That is, whenever the pattern of inattention to one's own good qualities is a result of caring about good things, Bommarito considers the agent in question to be humble. ${ }^{18}$

There are therefore three distinct requirements for humility within Bommarito's account of humility as a virtue of attention:

1. that one "have a good quality to be modest about"

2. that one "direct one's conscious attention in certain ways-away from the trait or its value or toward the outside causes and conditions that played a role in developing it"

3. that "the associated pattern of attention is a manifestation of morally good desires or values" 19

Bommarito does, however, allow that "modesty is not of equal importance to everyone," since he regards it as a counterbalance to a tendency to dwell on one's own successes, a tendency that is not universal ("Modesty as a Virtue of Attention," 116). In particular, it seems likely that such a tendency will be gendered, etc. 
The first condition Bommarito picks up from existing literature. ${ }^{20}$ The second condition is taken by him to be the core of his account; he describes humility as "rooted" in patterns of attention. The third condition is then introduced in order to secure the moral value of humility.

I want to raise concerns about each of the above conditions. First, I will argue that condition 1 is mistaken-one can be humble regarding failures as well as good qualities. Second, I will argue that condition 2 is unjustified, and rendered obsolete by 3. Most significantly, I will argue that 3 therefore ends up doing the work in this account, but is not sufficiently specific: we require a more complete account of which good values, desires, or concerns ground humility.

First, in condition 1 Bommarito suggests that humility is about particular good qualities that we possess. ${ }^{21}$ This, however, does not seem to quite match our ordinary conception of humility: humility can be exhibited as much in one's attitudes toward one's failures as one's attitudes toward one's successes. Gwendolen, for example, demonstrates a lack of humility through her behavior regarding her lack of musical talent. Uriah Heep similarly lacks humility though he has no impressive achievements or qualities. More generally, admitting to and apologizing when one is in the wrong is a paradigmatically humble action, though it is necessarily a response to failure rather than success. ${ }^{22}$ One can thus manifest humility in one's attitudes toward qualities that are not admirable as well as in one's attitude toward one's good qualities. ${ }^{23}$

Second, there are reasons to reject condition 2, that the humble person must direct their attention in the ways specified. Such an emphasis on attention

Tharcia's self-directed account in "Being Unimpressed with sumption, as does Raterman in "On Modesty." However, some recent writers have made exactly the opposite assumption, suggesting that humility requires limitations. Byerly ("The Values and Varieties of Humility") and Roberts and Cleveland ("Humility from a Philosophical Point of View") reject the idea that humility is a dependent virtue. Snow suggests that it involves acknowledgement of one's weaknesses ("Humility"); and more recently Whitcomb et al. suggest that humility is "having the right stance towards one's limitations" ("Intellectual Humility," 516). Ben-Ze'ev ("The Virtue of Modesty") and Um ("Modesty as an Executive Virtue") make the related claim that modesty is not a dependent virtue. In section 3, I suggest that humility is not a dependent virtue.

Murdoch, The Sovereignty of Good, 89, similarly discusses "the honesty and humility of the scholar who does not even feel tempted to suppress the fact which damns his theory."

This stipulation is perhaps influenced by the fact that Bommarito largely writes in terms of modesty rather than humility, though he explicitly states that he regards the two as interchangeable. It may make more sense to say that someone is modest about a particular quality or achievement than it does to say that they are humble about a particular quality or achievement. 
seems independently dubious, as well as questionable in light of the account itself. Consider the independent reasons. Humility can be manifested in many different ways: there are patterns of emotions, judgments, and action as well as attention that are characteristic of humility. For example, the humble person will characteristically take pleasure in others' successes, sympathize with others' failures, and be patient with others' shortcomings. The humble person's judgments are, similarly, likely to manifest their appreciation of others. They will also be motivated to act in ways that manifest these concerns. These are all important manifestations of humility, and plausibly manifestations of virtue. Bommarito's account, however, privileges patterns of attention over the other manifestations of humility, assuming that attention shifts are the explanatorily basic manifestations of humility. There seems to be no good reason for this assumption. ${ }^{24}$

Even by Bommarito's own lights it is hard to see why he focuses on attention rather than any other manifestation of humility. He claims that the patterns of attention he identifies count as humble and thereby virtuous because they manifest good concerns: "this connection between patterns of attention and values and concerns allows us to see what is morally good about modesty." 25 At this point, it seems far from obvious what work the idea of a pattern of attention is really doing in his account. In order to explain the goodness of exhibiting certain patterns of attention, Bommarito claims that such patterns manifest morally good cares or desires. But the goodness of humility then seems to be entirely dependent upon the goodness of the underlying cares or concerns rather than the pattern of attention. This suggests that the goodness of humility is more a matter of the concerns underlying a pattern of attention than the pattern itself. In this case, although the pattern of attention might result from such underlying concerns, it seems to be peripheral to humility itself, a mere symptom of the trait that is of moral significance.

Finally, the most serious problem facing the account is that condition 3 seems unsatisfactory without further specification of which particular desires, cares, or

24 Bommarito does suggest that the other manifestations can be understood with reference to patterns of attention. For example, attending to others' successes and achievements allows one to take pleasure in them ("Modesty as a Virtue of Attention," 115). However, it is far from clear that this is the right order of explanation. After all, it seems equally plausible to say that one is more likely to attend to things that one finds emotionally important. Although the two are interlinked, attention does not seem to be more foundational or explanatorily basic. I will suggest that a unified explanation of the emotions, judgments, patterns of attention, etc., that are characteristic of humility can be given by understanding them as manifestations of an underlying concern or value.

Bommarito, "Modesty as a Virtue of Attention," 104. 
values ground humble patterns of attention. ${ }^{26}$ First, desires, values, and concerns seem to each be fairly different. In a recent book, Bommarito argues that cares or concerns entail sometimes having certain desires, but can be contrasted with desires in that they are longer-term, persisting states:

Caring about something is an underlying, typically long-term, positive orientation to something.... To care about something means that it matters or is important to you in a deep way. ${ }^{27}$

Bommarito suggests that desires can be fleeting, but values, cares, or concerns are long-term states revealing something important about the orientation of our lives. It is possible, he claims, to care about something in the absence of an occurrent desire: one can care about a friend, for example, while one is consciously occupied only with working out a crossword. On his account, cares are connected with judgments of value, but not identical with them: for example, you can judge that "scholarship on economics in the history of Latvia" is valuable, without it mattering or being important to you. ${ }^{28}$ Given that humility, if a virtue, is a character trait, it seems that mere desire will not be sufficient to underlie it, and cares or concerns must underpin humility. ${ }^{29}$

However, Bommarito underemphasizes the significance of particular cares or concerns in his account. Without identifying the particular cares or concerns that underpin humility this account overgenerates instances of it. There are morally good cares or concerns that give rise to patterns of attention along the lines Bommarito envisages that seem to have little or nothing to do with humility. For example, one might care about a friend who is keen on poetry and, as a result, always attend carefully to skillful poetry readings in order to be able to tell one's friend about them. While this might make one a good friend (which seems like a good quality), it seems to say nothing about one's level of humility. Not every pattern of attention regarding one's good qualities that manifests a morally good concern will thus reflect one's humility. Humility is therefore more dependent upon particular cares or concerns than Bommarito recognizes, and Bommarito lacks a full account of which particular cares it depends upon.

Bommarito thus fails to offer a satisfactory account of humility. There is reason to doubt condition 1, that one must possess a good quality to be humble about. Condition 2, the attention constraint, seems to privilege attention over

This is perhaps unsurprising, since Bommarito suggests that there are many different virtues of attention.

Bommarito, Inner Virtue, 29.

That is, assuming the standard conception of a virtue as something like a character trait. 
the other manifestations of humility in a way that is independently implausible, and unnecessary given 3. Finally, although Bommarito seems right to introduce condition 3, that the humble person must care about or value the right kinds of thing, the particular cares that underpin humility need to be identified. In the absence of an account of the particular cares that underpin humility, this account overgenerates instances of humility. In the next section, I will propose an account of humility in terms of the particular things that the humble person cares about or values.

\section{THE VIRTUE OF HUMILITY AS NOT \\ VALORIZING BEING RELATIVELY SUPERIOR}

The strength of Bommarito's account, I have suggested, is that it offers a way of unifying the self- and other-directed poles of humility. I have argued, however, that his focus on patterns of attention fails to identify the core of humility. Condition 3, the idea that the humble person cares about certain things, was introduced by Bommarito in order to explain why certain patterns of attention are morally significant. The things one cares about do seem relevant to whether one is humble. In this section, I will suggest that a particular care or value forms the core of humility. I will explain and motivate this account of humility and give some reasons to think that humility thus conceived is a virtue. In the next section I will defend this account against three important objections.

The variety of ways in which humility can be manifested suggests that it is not best characterized by any particular manifestation. Rather, Bommarito seems right to suggest that it has much to do with the underlying things the humble person cares about. My suggestion is that the humble person does not valorize being relatively superior. ${ }^{30}$ That is, the humble person is not concerned with relative positionings and does not intrinsically value being relatively better off than others. To "valorize" relative superiority is to "care" about it in the sense outlined by Bommarito above. The humble person might value her good qualities or achievements for their own sake, but not for their impact on hierarchical ranking. This lack of valorization by the agent of relative positionings cannot be the result of mere indifference to the quality, activity, or achievement in question as a whole, but must concern qualities, activities, or achievements that the agent

Roberts and Cleveland make the similar suggestion that "the virtue of humility is intelligent lack of concern for self-importance, where self-importance is construed as conferred by social status, glory, honor, superiority, special entitlements, prestige, or power" ("Humility from a Philosophical Point of View," 33). However, they explore it primarily by contrasting it with pride. 
cares about. A lack of interest in relative positionings that results from mere indifference to the quality would not suggest anything about the agent's overall character, whereas not valorizing relative positionings concerning things one cares about seems to indicate something far more substantial about the agent.

On this account, to be humble regarding $x$ is

1. to care about $x$,

2. to not valorize being relatively superior regarding $x .^{31}$

As I noted above, however, humility does not seem to always take this specific form: we do not always think of humility as being "about" anything in particular. We naturally speak of "humble people" and take humility to be a general trait that one can possess. This kind of general humility can be understood on the same model as the more limited forms.

To be humble in general is

1. to not valorize being relatively superior. ${ }^{32}$

The person who is generally humble simply does not value being relatively superior. She is not status conscious; she does not value being high up in a hierarchy herself, nor does she care about others' hierarchical positionings. ${ }^{33}$ This explains why, for example, Gwendolen is not generally humble as a person. Her care about relative positioning means that music can have no role in her life if she is not highly ranked musically: she refuses to allow herself to value things that do not increase her relative positioning.

This account therefore avoids making humility a dependent virtue (as it is on Bommarito's account) since one can valorize being relatively superior whether or not one is actually superior. ${ }^{34}$ Simply caring about being relatively superior, on this account, counts against humility, regardless of whether one is actually

The variable here could be read as referring to a character trait, an activity, or a particular achievement. One could be humble about one's athletic capacities, about athletics, or about winning a particular race, for example.

32 That is, assuming that one has a range of things one cares about, which seems essential for an ordinary human life.

33 This allows that the humble person might care about relative positioning in some sense, for example, by desiring an egalitarian society.

34 If modesty is taken to be dependent on achievements or good qualities, this gives a way of distinguishing the two: humility, unlike modesty, does not depend on the possession of a good quality, and is not about any particular quality. It is a more complex character trait than modesty. That there is some difference is suggested by the fact that in ordinary language there seem to be cases where attribution of modesty, but not of humility, would be appropriate. 
superior. A person who is jealous or envious of another, for example, might very much valorize being relatively superior, while not themselves being at all superior. Not valorizing relative superiority, then, means that to the extent that they are superior to others they do not value this, and to the extent that they are not superior they do not desire to be. ${ }^{35}$

What would humility look like? Imagine Anna, a humble runner. She counts as humble if she cares about being a good runner but does not intrinsically care about being better than other runners. And Anna would be humble not only regarding running but generally if she does not valorize being better than others generally.

This account does not entail that concern at being worse than others necessarily indicates a lack of humility. The agent might take such relative positioning merely as an indication that they could be doing much better than they are and that they therefore have reason to put more effort into the area in question. ${ }^{36}$ Only if their concern is for their relative positioning itself, rather than for what it might indicate, does the concern entail a lack of humility. For example, Anna might be disappointed to come last in a race. If this disappointment were disappointment at her relative position, she would not be humble. But her disappointment could well be because losing is an indicator that she could be doing better, and such disappointment would be compatible with humility.

\subsection{Advantages of the Account}

On this account, not valorizing being relatively superior is what constitutes humility. What we valorize or care about shapes our emotions, judgments, and actions, so this account of humility is well placed to explain the patterns that are characteristic of humility. In this section, I will identify some commonly accepted core features of humility and show that they are well explained by understanding humility as not valorizing being relatively superior.

The pattern of attention that Bommarito highlights is explained by this account: the humble person has little motivation to attend excessively to their own good qualities, since doing so would not be a source of comparative pleasure.

One might worry that giving up on humility being a dependent virtue makes it too easy to attain. Should the unaccomplished but lazy person, for instance, really count as humble? I think that two responses are available. First, if the lazy person's laziness is incompatible with their caring about excellence in the respect in which they are unaccomplished, then they would not count as humble on the account I am offering. If, on the other hand, the lazy person can still care about the activity in question, then I think that they should count as humble. Such a person might lack ambition or drive, but these are distinct traits from humility. Thanks to an anonymous reviewer for raising this worry. 
Neither would they be motivated to attend excessively to themselves through an anxious concern that others might be better off than them. The account allows that the humble person might nonetheless sometimes attend to their good qualities but rules out this attention being motivated by comparative concerns. ${ }^{37}$

Moreover, the humble person's tendency not to valorize being relatively superior can shed light on the various emotional manifestations of humility. Since the humble person does not valorize their relative positioning, they are likely to feel neither self-aggrandizing pleasure at being better than others in particular respects, nor envy, jealousy, or shame simply at being less good than others. Anna, for example, would not feel distress if other runners are faster or have greater endurance than her. Moreover, the humble person is unlikely to make anxious comparative judgments between themselves and others, because others' success would not constitute a threat to them. ${ }^{38}$ The humble person is likely to be good at taking pleasure in others' success, and feeling sympathy for their setbacks. This is because one significant barrier to such empathy has been removed: the selfish concern that others' success might relatively downgrade or upgrade one's own position. ${ }^{39}$ Moreover, they are unlikely to feel complacency about themselves, since even if they are doing well on a relative scale, it is unlikely that they have realized the good quality in all its fullness.

The expectations we have concerning how a humble person would act can also be explained by this account. The humble person, I take it, is characteristically good at recognizing their shortcomings. That is what we would expect if are not concerned that such shortcomings would relatively downgrade them. They are also characteristically good at apologizing for the effects of such shortcomings. Again, that is what we would expect on the present account: for the humble person, such apologies do not lower them in any important way. The humble person is characteristically willing to spend time and effort on others' behalf. This, too, makes good sense, since on the present account the humble person does not feel threatened by others' success. ${ }^{40}$

This also allows that the humble person might attend to their good qualities in order to improve themselves, which Bommarito is keen to allow for.

There are some reasons why the humble person might nonetheless make anxious comparative judgments. For example, they might be aware of their high achievement in a particular field and be anxious to not make others feel bad. But one kind of anxious comparative judgment, where one's anxiety is about one's own status, is inconsistent with humility.

As a result of the humble person's increased capacity to take pleasure in others' success, they are likely to be alert to others' needs and willing to help others without feeling any threat to their own positioning. As such, this explains the "focus" on others that Nadelhoffer et al. describe as central to humility ("Some Varieties of Humility Worth Wanting"). 
As we have seen, Bommarito notes that the humble person is more likely to be aware of the contingent factors that have led to their successes, as well as the ways in which their achievements have been dependent upon good fortune and the help of others. ${ }^{41} \mathrm{He}$ suggests that humble people therefore typically express greater gratitude than non-humble people. For example, on winning a race, Anna might be likely to thank those who supported her and acknowledge their contributions to her success. This too is explicable on the present account. Awareness of one's dependence on other people as well as contingent strokes of fortune seems to destabilize one's position in a hierarchy. It makes one's position dependent on factors outside of one's control, things that could have been otherwise. As such, the person who valorizes their relative positioning is likely to find it unpleasant to recognize the role that such factors have played in their success and, therefore, would be reluctant to do so.

This account also sheds light on why Uriah Heep's continual assertions that he is humble are so grating. Uriah spends the whole of David Copperfield anxiously attempting to improve his comparative position. It matters very much to him that he should be considered, and that he should regard himself, as relatively more successful than others. As such, he takes pleasure in setbacks faced by those around him and is wholly unable to appreciate others. His general unpleasantness is therefore amplified by his asserting his own humility in the service of precisely the kind of one-upmanship that humility guards against.

Uriah Heep's assertions of his own humility are not only strange because of their contrast with his wider behavior but reflect something generally perplexing about such assertions. There seems to be something odd about making such claims at all, an oddness that would not disappear if Uriah did in fact generally act humbly. Heep's assertions serve to constantly call attention to his "humility" in a manner that suggests an air of competition: he wants his humility to be recognized, and wants himself to be regarded as more humble than others. ${ }^{42}$ This suggests that what is paradoxical about his assertions is at least in part that in making them he suggests that he is better with regard to humility than others: he regards his humility as worth calling to others' attention because he regards

ly good at listening and taking advice.

Bommarito's suggestion is stronger than this: on his account such awareness is (partially) constitutive of humility.

Of course, there are some cases in which assertions of one's humility do not have this competitive or comparative character. Raterman notes that in a "quiet conversation with a good friend about the personal qualities one values possessing," asserting that one is humble may be entirely consistent with modesty ("On Modesty," 232). My explanation accounts for why such self-assertions are often perplexing without implying that all instances are strange or self-undermining. 
himself as more humble than others. ${ }^{43}$ A truly humble person would not value such relative ranking, and thus would feel no need to self-ascribe humility in this way. ${ }^{44}$

\subsection{Humility and Virtue}

As with Bommarito's account, this understanding of humility suggests that humility is likely to have good consequences. For example, humble people are likely to cause less social friction since they are likely to be more attuned to the needs of others. Conversely, the humble person would be more able to share in the happiness of others. I suggested above that they are also more likely to be aware of and grateful for others' roles in their successes. These seem like valuable consequences of humility. But this account allows for more than this to be said: it explains why humility is intrinsically valuable, and as such, it plausibly explains why humility is a virtue.

The humble person does not valorize being relatively superior. The central reason why this is morally valuable is that valuing relative superiority over others seems to involve a failure to properly value other people. In wanting to be superior to others, I fail to fully appreciate them and recognize their worth. Valorizing being superior to others (as opposed to wanting to be excellent) seems to involve valuing looking down on others, which is in tension with adequately valuing them. Since recognition of such worth is centrally morally important, humility is an important moral virtue. ${ }^{45}$

Moreover, this trait is virtuous to the extent that the humble person is free to value the right kind of thing: the humble person can recognize that being good

Similarly, imagine saying at a philosophy conference that one is good at philosophy. While the sentence might be apt in a room of nonphilosophers, at the conference it would imply that one is better than others, or notably good.

44 Others have suggested alternative explanations of the oddness of assertions of one's humility. Driver suggests that humility requires ignorance of one's self-worth, and thus that the humble person must be unaware of their own humility ("The Virtues of Ignorance"). Kellenberger suggests that one might recognize one's own humility, but could not generally assert that one is humble ("Humility"). Bommarito suggests that the humble person would not dwell upon or draw others' attention to their own humility, but that one can know of one's own humility ("Modesty as a Virtue of Attention"). Like the latter two, my explanation of the oddness of assertions of one's humility allows that the humble person might recognize this about themselves. It suggests that the humble person would be generally unlikely to assert that they are humble, but such assertions would not be incompatible with humility.

45 That valorizing relative superiority involves a failure to properly value others suggests a connection between humility and love. Since love plausibly involves a certain kind of appreciation or valuing of others, humility seems to be necessary for love. 
itself is what matters, rather than relative rankings. Gwendolen's inability to enjoy music once she realizes that she has no exceptional talent suggests a kind of failure in her valuing of it in the first place. Her excessive valorization of her own relatively elevated musical status is at the expense of truly caring about music itself. This seems like a general feature of valorizing one's relative ranking: such a care seems to be wrongly oriented and to indicate a lack of concern for goods or activities according to which there is a tendency to rank ourselves. At the extreme, such activities, qualities, or achievements become wholly fungible, since engaging with the activity becomes a mere means to hierarchically raise oneself. $^{46}$ The humble person, then, avoids one important way in which our valuing can be distorted. ${ }^{47}$

Returning to the worries raised in the introduction about humility, we can therefore see that humility need not involve inferiority or servility. Not valorizing relative superiority leaves open whether one takes pleasure or pride in one's achievements, and whether one is able to recognize one's good qualities. These seem sufficient to ground a sense of self-worth that is in tension with servility and inferiority. Servility entrenches one form of hierarchy, social hierarchy. But far from serving to entrench and justify social hierarchies, humility is connected with resistance to such hierarchy. The individual who does not valorize their own relative superiority is likely to do so because they do not valorize relative superiority in general. ${ }^{48}$ Undue acceptance of inferiority and subservience, however, seem to involve an acceptance of a social hierarchy that is in tension with not valorizing relative positioning in general. That is, acceptance of social hierarchy seems to depend on valorizing relative positionings, on viewing those in certain positions as better in virtue of their position. Humility thus need not involve inferiority or servility, and is in tension with some of the assumptions that un-

46 It might be the case that having some talents better enables one to appreciate certain activities or achievements, so it is not necessarily an indication of lack of humility if someone particularly enjoys those activities they are good at. What would indicate a lack of humility would be if they enjoyed those activities they are good at only because they get the satisfaction of being better than others.

47 Schueler suggests a similar account of humility ("Why Modesty Is a Virtue"), which he later explicitly links with the idea of "ranking" ("Why IS Modesty a Virtue?"). However, he gives a different argument for this, suggesting that such a trait is valuable because the goals and purposes of a person who cares whether others are impressed with them for their accomplishments are shaped or created by others: "to the extent that someone cares about whether people are impressed with her accomplishments, the direction of her life comes not from within herself but from others" (Schueler, "Why IS Modesty a Virtue?" 839).

48 Not valorizing relative rankings need not entail that one could not attend to such rankings at all. After all, rankings might be used merely as indicators of intrinsic value or worth. 
derpin such attitudes. This account therefore avoids the politically concerning connotations of humility. ${ }^{49}$

\section{THREE OBJECTIONS TO THE ACCOUNT}

Having proposed and motivated my account, I will now turn briefly to answer three objections to it. First, I will explore how the humble person can participate in competitive activities; second, I will examine whether caring about activities in themselves is compatible with caring about one's relative positioning; and finally, I will answer the objection that on this account humility is compatible with caring too much about one's achievements.

\subsection{Objection 1: Humility and Competitive Activities}

Are there not some cases in which valorizing one's relative positioning is unproblematic? Is valorizing one's relative positioning always a bad thing? While caring about being a good host for the sake of improving one's relative social positioning seems like a bad thing, there are some cases where the status of valorizing one's relative positioning seems less clear cut. Most prominently, it may seem that aiming to be better than others is integral to some competitive activities such as sports and games. ${ }^{50}$ Moreover, it can seem that valorizing relative positioning is necessary for success in such activities. Take, for example, playing chess. It can seem impossible to participate in playing chess if one is not aiming to win (a matter of relative positioning), and it can seem impossible to be a good player without valuing winning. This poses a problem, because it seems that there can be humble people who participate in such activities.

Such cases pose a problem because excellence in such activities necessarily involves valuing relative victories. To be a good chess player involves having the capacity to beat others in a game of chess, the capacity to gain relative victories. My account of humility will not straightforwardly cover such cases. But on consideration, that should not be surprising: few ordinary virtues and vices seem to straightforwardly apply to games. A good Monopoly player is likely to exhibit avarice that would be condemnable outside the game, and a generous Monopoly player who shared their gains with others would be very dull to play with. None-

49 An implication of this is that on this account, humility has a lot more to do with being humbled (which need not be unpleasant) than with humiliation.

50 Austin argues that humility is a virtue in the context of sport ("Is Humility a Virtue in the Context of Sport?”). However, his conception of humility involves elements of self-lowering that mine does not. 
theless, the present account explains how people participating in competitive activities can be humble. $^{51}$

When aiming to win is an integral part of an activity itself, humility cannot simply be a matter of not aiming to gain a relative victory, since aiming to win is aiming to beat one's opponent. But there are nonetheless different reasons one might have for aiming to win. It seems unobjectionable to want to win simply because one valorizes being good at chess. But wanting to win because one valorizes being relatively superior to one's opponent does seem to be objectionable. In the former case, caring about relative superiority is compatible with humility: the player does not primarily or intrinsically valorize their relative positioning. In the latter case, however, the motivation seems morally objectionable, and at odds with humility. In the context of competitive activities, valorizing relative superiority is acceptable insofar as it is valued merely as something entailed by excellence in the activity or for some similar reason. However, caring about winning simply as such would rule out humility. ${ }^{52}$

Moreover, not valuing one's relative positioning, or valuing it only insofar as it is necessary for excellence in the activity in question would leave one well placed to cope with not being the best at the activity in question. The humble person is well placed to be accepting of their losses while valuing their achievements. Returning to Anna, the humble runner, we can imagine her losing a race. Such a loss would not be likely to eventuate in bitterness or resentment toward the winners. Indeed, if she had run well, then she could well feel satisfaction in her achievement despite the loss. Moreover, she would be likely to admire people who are better runners, value their achievements, and perhaps attempt to emulate them in the future. Anna would therefore be well positioned to improve her skills and become a better runner. ${ }^{53}$

One important thing to note here is that games, where excellence is necessarily indexed to relative positioning, are more highly socially constructed than activities like cooking. I am suggesting that with regard to such activities, valorizing relative positioning might be permissible as long as there is independent justification for the activity, and if the relative positioning is not valued or pursued for its own sake, but as a part of the game.

52 Roberts and Cleveland similarly note: "To be invidious, the kind of superiority that the prideful individual prizes has to be noninstrumental. For example, athletes typically want to outdo their competitors, but this concern for superiority need not be invidious, because it can be teleologically subordinate to winning the game, which may be merely playful" ("Humility from a Philosophical Point of View," 35).

It is an interesting feature of this account that it gives us resources to critique current social practices that foster competitiveness. Not all environments are equally conducive to virtue. Social practices that foster valorizing relative superiority rather than valuing achievements for their own sake will not be conducive to virtue, and this seems like a reason to at least alter them. 


\subsection{Objection 2: Compatible Cares}

Another objection that might be raised at this point is that humans generally care about many different things. As such, it might seem possible for one to care about both relative positioning and activities or ends in their own right. If one could care about both things, then many of the purported reasons why humility is valuable would seem to be undercut.

A person who valued achievements, qualities, or activities in themselves but also valued being relatively superior would, however, still be regarding others in a problematic way. That is, their valuing being superior to others would constitute a failure to properly value others. Although the person who valued things in themselves as well as relative positioning concerning those things would perhaps be better off than the person who valued only relative positioning, they would still lack much that is of moral significance.

Caring about rankings is thus in tension with properly valuing activities, qualities, and achievements. Ranking individuals with respect to an activity seems to depend upon a flattening out of the valued realm. Determining who is better, even with regard to a relatively narrow realm, is a difficult task. In order to rank individuals, we thus tend to pick out a couple of fixed dimensions along which to evaluate. But our appreciation of the activities, qualities, and achievements characteristically extends far beyond these few dimensions, and we particularly value the ways in which people's contributions can be unique and interesting. Caring about ranking therefore seems to flatten out the rich and interesting ways in which a performance can be good. This suggests that caring about being better than others can lead to a kind of distortion in our appreciation of activities or performances themselves. For example, imagine trying to determine who is the better ballet dancer. There are certain things we could measure: the number of pirouettes they can turn, the height to which they can extend their leg in an arabesque, the elevation they reach in jumps. But obviously none of these (even taken together) seem like plausible candidates for determining who is the better dancer; there are many varied ways in which one can achieve excellence as a ballet dancer. It seems like most activities that we value are like this: there are many ways of achieving excellence at them, and often we particularly value the original and unusual ways of doing so. This therefore implies that we do not get the appreciative benefits of valuing things in themselves unless we do not care about relative rankings.

Finally, the benefits of caring about achievements, qualities, and activities are often dependent on not caring about relative superiority. Pleasure in achievement can be undercut by caring about one's relative positioning. That is, there 
are many instances where one will have achieved something valuable that is not itself a relative achievement, and similarly there will also be cases where one has made a relative achievement but not performed well. In such cases, valuing relative achievement will undercut the pleasure (or displeasure) one would take in the performance itself. We would thus fail to get the benefits of caring about something without also being humble with regard to it.

\subsection{Objection 3: Humility and Pride}

As I noted earlier, on this account humility is not incompatible with pride. This opens up space for a possible objection to the account: Does this account allow for the humble person to care too much about their achievements? That is, is humility on this account consistent with an excessive pride in one's achievements?

In answer to this, it is important to first note that I take the compatibility of humility with pride in one's achievements or good qualities to be a virtue of the account. It coheres with our intuitive thought that taking pride in our successes is a good thing. It also seems important to motivate us to participate in such activities in the first place and to be necessary for adequate practical reasoning: recognizing and valuing when one has done well seems essential to knowing how one should improve.

Pride per se, then, does not seem to be necessarily problematic. What seems problematic is arrogant pride, or pride whereby one looks down on others or sees oneself as superior to them. Such superiority, haughty disdain, and contempt for others are clearly inconsistent with humility on this account: valorizing being relatively superior is a necessary condition for the objectionable kind of pride. When such pernicious underpinnings of pride are absent, it does not seem objectionable. For the same reason, by-products of pride like bragging are ruled out on this account: bragging functions on the presupposition that one is not merely good but better than others (stating that one has swum one hundred meters in two minutes might constitute bragging in some contexts, but not in a room of Olympic swimmers).

The objection might then be reformulated as follows: I have said that humility is consistent with some pride. But what if a person cares only about their own achievements (in nonrelative terms), and simply fails to care about others' (nonrelative) achievements at all? Would such a person not lack humility? There would certainly be something wrong with such a figure, but I think it would be incorrect to say that they lack humility. Their behavior would rather seem to be somehow pathological. Think, for example, of the people who most frequently exhibit such patterns of caring: very young children. Very young children do, for example, show great pride in their scribblings, while remaining unmoved by 
great works of art. But we would not think of them as lacking in humility as a result of this. Rather, their failure to care about others' equivalent achievements is seen as resulting from the fact that they are not fully developed as moral agents or practical reasoners. It therefore seems inappropriate to describe them as either humble or lacking in humility. By contrast, if an adult were to act in this way, it would be pathological. It seems that it would be inapt to describe a person with such a pattern of caring as either humble or lacking humility: their pattern of care is, rather, disordered in a different respect.

\section{HUMILITY AND ETHICAL DEVELOPMENT}

Humility, then, seems to qualify as a virtue. However, I began with Murdoch's suggestion that humility also plays a significant role in ethical development. ${ }^{54} \mathrm{I}$ am taking "ethical" development to be broader than narrow moral development, although ethical development will have a distinct moral dimension. ${ }^{55}$ In the answer to the above objection concerning competitive activities, I suggested that Anna, the humble runner, would be well placed to develop her talents. Although humility is no guarantee of development, my claim is that it generally puts one in a good position to develop ethically. This provides a limited vindication of Murdoch's claim that "although he [the humble man] is not by definition the good man perhaps he is the kind of man who is most likely of all to become good." 56

In the example from Daniel Deronda, Gwendolen's lack of humility is made apparent in her inability to appreciate music once she realizes that she has no exceptional talent. This lack of humility forms a formidable barrier to her becoming a better person. Gwendolen, although utterly selfish, has some capacity to perceive her own need to change. But she is prevented from doing so by her felt need to maintain her superiority. She is resolute in preventing others from recognizing that they are in some respects better off than her (hence her unwill-

54 Clifton also notes Murdoch's claim that the humble person is the most likely to become good. He suggests that this is explicable "because of his self-abnegation, which opens up possibilities for displaying attention to the world" ("Murdochian Moral Perception," 212). However, Murdoch states that "humility is not a peculiar habit of self-effacement," which seems to resist this interpretation (The Sovereignty of Good, 95). I am proposing a way of connecting humility with moral growth without understanding humility as involving self-abnegation.

This is particularly clear if one regards the virtues as kinds of skill (see, e.g., Annas, Intelligent Virtue).

56 Murdoch, The Sovereignty of Good, 101. In a recent paper, Soyarslan notes that Spinoza suggests that humility is not itself a virtue, but can be useful as a means toward virtue, though only for "weak minded" people ("From Humility to Envy"). 
ingness to tell anyone but Daniel of her unhappiness), but also unwilling to admit this to herself. Since she cannot bear to consider herself as lesser than others in any respect, she is therefore unable to appreciate how to become better. Her valorization of her relative positioning also prevents her from responding in the right way to those deficiencies in herself that she can perceive: she is both unable to see how to become better and unable to become better.

I will suggest that this is a general feature of humility. Humility is not only, as I suggested above, intrinsically valuable but also importantly connected with ethical development, the process of becoming better. As illustrated with the case of Gwendolen, humility is important for both epistemic and motivational reasons. It removes barriers to developing the knowledge necessary for ethical development (knowledge about how to become better), and also removes barriers to being motivated in ways that aid ethical development. It therefore has an important role in ethical development.

First, humility has some direct epistemic benefits. It removes one significant motivation for distortion in our beliefs about ourselves, allowing us to recognize our successes and failings as such. Since the humble person does not valorize being relatively superior, they lack a significant motivation to distort what they see in order to reassure themselves that they are relatively more successful than others. They would also lack a significant motivation to regard their own achievements as uniquely admirable or worthy. They are thus more likely to be able to perceive the true value of their own qualities and achievements. Such recognition seems crucial to improvement, since improvement requires recognizing when one has done well or badly. That is, recognition of one's failings as such is necessary if one is to know where to improve. The ability to recognize the ways in which one's successes are the result of others' assistance or good fortune, an ability characteristic of the humble person, is also likely to enable one to have a realistic vision of developing one's skills. ${ }^{57}$

Moreover, the humble person will be more likely to recognize the valuable achievements or qualities of others as such. They lack a significant motivation to anxiously look for reasons to think of others' achievements as less significant than they are, and are therefore likely to be able to recognize others' achievements. As a result, they are also likely to be well guided in their own attempts to improve, since accurately recognizing others' achievements enables one to have good models of how to be successful, and to choose wisely whom to emulate.

Humility also has some indirect epistemic benefits. The humble person is dent Rational Animals, 133). 
typically a good listener and able to take advice from others. ${ }^{58}$ They are likely to be willing to listen to others in the first place and to not be dismissive of what others have to say. They are thus well positioned to gain knowledge that enables them to become better. Since they do not care about being relatively superior, they are likely to be less invested in pernicious stereotypes about what others have to teach us. Properly listening to someone involves thinking that the speaker might have something to tell us, that they may know some things that we do not. It thus involves attributing (possible) epistemic goods to others and acknowledging that we may not possess such goods. This acknowledgement can grate against a felt need to assert our own rightness, or to see ourselves as the ones with knowledge, with greater epistemic authority or success. For the person who valorizes being relatively superior, such acknowledgement will be particularly painful, and thus they are likely to be motivated to avoid it. But the humble person is not threatened by the thought that others may possess epistemic goods that they do not. They are not invested in the idea that others are "below" them on some hierarchical scale, nor that they are unlikely to have anything of note to communicate. A significant barrier to being a good listener and being good at taking advice is therefore missing in the humble person, enabling them to gain important knowledge. ${ }^{59}$ Humility therefore lessens one important barrier to ethical growth, lack of knowledge, both by removing a distorting factor in our judgments and by removing an obstacle to receiving testimony. ${ }^{60}$

Second, humility is important for ethical growth because it involves motivational or affective responses that aid ethical development. That is, it enables us to react in the right kinds of way to our own and others' achievements and failures. Recall the example of the humble runner, Anna. On recognizing that another person is a better runner than she is, she would not feel envy or resent-

58 Fricker suggests that there are certain virtues involved in being a good listener in this sense (Epistemic Injustice). She refers to these as virtues of testimonial and hermeneutical justice. The humble person, I have suggested, will be a good listener in a slightly broader way than in the way she picks out, but would be likely to also possess the virtues she identifies.

Such advice or testimony might be moral or nonmoral, but seems particularly important in the moral case.

60 Tanesini discusses the moral and epistemic viciousness of intellectual arrogance. My account of arrogance has parallels with what she calls "haughtiness," something that "manifests itself through disdain for other people.... Arrogance of this kind is often identified with a feeling of superiority over others" (Tanesini, “'Calm Down, Dear,” 73). She suggests that such haughtiness involves the presumption that one is exempt from the ordinary responsibilities of conversational participants, and can lead to silencing. As such, she argues that it fosters ignorance. Although my claim is about general lack of humility rather than specific intellectual arrogance, this seems to me like a plausible account of some of the ways in which a lack of humility can be epistemically harmful. 
ment. Rather, though she may feel disappointment at her own performance, she is also likely to feel admiration for the other runner's achievement. Anna's response seems like the appropriate response to admirable achievements. But it also seems likely to help her become a better runner through motivating her to emulate the person in question. By contrast, the person who recognizes that the other runner is better but feels only envy or resentment is likely to feel equally motivated to "pull down" the better runner as they are to improve themselves. This is what happens with Uriah Heep, who recognizes others' successes but is led to hope (and scheme) for their downfall.

For the person lacking humility, recognizing others' relative superiority can lead to sour grapes, where they feel discouraged from participating in the activity at all, regarding it as not worth trying. This is what happens with Gwendolen: her lack of relative success discourages her from appreciating or participating in music. Faced with the fact that others are more musically talented than her, Gwendolen cannot bear to think that music is valuable at all. As such, she forfeits any chance to improve musically, as well as the opportunity to appreciate music itself. By contrast, the humble person is not only in a good position to recognize others' successes but is also disposed to react to such successes in ways that enable them to emulate such success and, therefore, to become better at the activity in question.

Humility, then, removes common barriers to ethical development that are both epistemic and motivational. As a result, the humble person is disposed to become better. This does not guarantee that the humble person will develop ethically, since other obstacles might stand in their way, but it at least suggests that they are well placed to do so. This vindicates Murdoch's claim that the humble person is likely to become good. ${ }^{61}$ Humility is thus an interesting trait and one worth seeking for two reasons: not only because it is a virtue, but because it plays an important role in our ethical development. ${ }^{62}$

\section{Wadham College cathy.mason@wadham.ox.ac.uk}

61 Murdoch makes the stronger claim of the humble person that "perhaps he is the most likely of all to become good." This is seemingly a result of her view that the "anxious ego" is the primary obstacle to moral growth. I have provided an argument only for the claim that humility is an important condition for ethical growth, not that it is the most important condition for it. Murdoch is, however, seemingly hesitant in making this claim, and thus it seems that my argument captures the spirit of her remark.

62 I would like to thank Paulina Sliwa, Matt Dougherty, Lucy McDonald, Karam Chadha, Maxime Lepoutre, Annie Bosse, and two anonymous reviewers for helpful comments and feedback. 


\section{REFERENCES}

Annas, Julia. Intelligent Virtue. Oxford: Oxford University Press, 2011.

Austin, Michael W. "Is Humility a Virtue in the Context of Sport?" Journal of Applied Philosophy 31, no. 2 (May 2014): 203-14.

Ben-Ze'ev, Aaron. "The Virtue of Modesty." American Philosophical Quarterly 30, no. 3 (July 1993): 235-46.

Bommarito, Nicolas. Inner Virtue. Oxford: Oxford University Press, 2018.

—. "Modesty as a Virtue of Attention." Philosophical Review 122, no. 1 (January 2013): 93-117.

Byerly, T. Ryan. "The Values and Varieties of Humility." Philosophia 42, no. 4 (December 2014): 889-910.

Calhoun, Cheshire. "On Being Content with Imperfection." Ethics 127, no. 2 (January 2017): 327-52.

Clifton, W. Scott. "Murdochian Moral Perception.” Journal of Value Enquiry 47, no. 3 (September 2013): 207-20.

Dickens, Charles. David Copperfield. Oxford: Oxford University Press, 2016.

Driver, Julia. Uneasy Virtue. Cambridge: Cambridge University Press, 2001.

- "The Virtues of Ignorance." Journal of Philosophy 86, no. 7 (July 1989): 373-84.

Eliot, George. Daniel Deronda. New York: Harper and Brothers, 1876.

Flanagan, Owen. "Virtue and Ignorance." Journal of Philosophy 87, no. 8 (August 1990): 420-28.

Fricker, Miranda. Epistemic Injustice: Power and the Ethics of Knowing. Oxford: Oxford University Press, 2007.

Garcia, J.L.A. "Being Unimpressed with Ourselves: Reconceiving Humility." Philosophia 34, no. 4 (December 2006): 417-35.

Kellenberger, James. "Humility." American Philosophical Quarterly 47, no. 4 (October 2010): 321-36.

MacIntyre, Alasdair. Dependent Rational Animals. London: Duckworth, 1999.

Morgan-Knapp, Christopher. "Comparative Pride." The Philosophical Quarterly 69, no. 275 (April 2019): 315-31.

Murdoch, Iris. The Sovereignty of Good. London: Routledge and Kegan Paul, 1970.

Nadelhoffer, Thomas, Jennifer Cole Wright, Matthew Echols, Tyler Perini, and Kelly Venezia. "Some Varieties of Humility Worth Wanting." Journal of Moral Philosophy 14, no. 2 (February 2017): 168-200.

O'Hagan, Emer. "Modesty as an Excellence in Moral Perspective Taking." European Journal of Philosophy 26, no. 3 (September 2018): 1120-33. 
Priest, Maura. "Intellectual Humility: An Interpersonal Theory." Ergo 4, no. 16 (2017): 1-18.

Raterman, Ty. "On Modesty: Being Good and Knowing It without Flaunting It." American Philosophical Quarterly 43, no. 3 (July 2006): 221-34.

Richards, Norvin. "Is Humility a Virtue?" American Philosophical Quarterly 25, no. 3 (1988): 253-59.

Roberts, Robert C., and W. Scott Cleveland. "Humility from a Philosophical Point of View." In Handbook of Humility, edited by Everett. L. Worthington, Don. E. Davis, and Joshua N. Hook, 33-46. Abingdon, UK: Routledge, 2016. Schueler, G. F. “Why IS Modesty a Virtue?” Ethics 109, no. 4 (July 1999): 835-41. . "Why Modesty Is a Virtue." Ethics 107, no. 3 (April 1997): 467-85.

Sinha, G. Alex. "Modernizing the Value of Humility." Australasian Journal of Philosophy 90, no. 2 (2012): 259-74.

Slote, Michael. Goods and Virtues. Oxford: Clarendon Press, 1983.

Snow, Nancy E. "Humility." The Journal of Value Enquiry 29, no. 2 (June 1995): 203-16.

Soyarslan, Sanem. "From Humility to Envy: Questioning the Usefulness of Sad Passions as a Means towards Virtue in Spinoza's Ethics." European Journal of Philosophy (forthcoming). Published ahead of print, December 3, 2018. https://doi.org/10.1111/ejop.12422.

Tanesini, Alessandra. "'Calm Down, Dear': Intellectual Arrogance, Silencing and Ignorance." Aristotelian Society Supplementary Volume 90, no. 1 (June 2016): 71-92.

Um, Sungwoo. "Modesty as an Executive Virtue." American Philosophical Quarterly 56, no. 3 (July 2019): 303-17.

Whitcomb, Dennis, Heather Battaly, Jason Baehr, and Daniel Howard-Snyder. "Intellectual Humility: Owning Our Limitations." Philosophy and Phenomenological Research 94, no. 3 (May 2017): 509-39. 